\title{
LOKPAL Bill - A powerful tool to control the Corruption: Opinion of Indian Voters'
}

\author{
Amitabh Bhargava, Harsh Purohit, Deepshikha Bhargava
}

\begin{abstract}
Corruption in India is a burning issue and poorly disturbs its economy. Majority of corruption is found during the program or schemes funded by the government for citizens or specific group of people. The voters of India are now aware about their rights and importance of vote. They are usually found in favor of developing a system to control the corruption. The Lokpal bill against corruption has been found as a strong tool but it couldn't yet implemented in its sprit and expectation. The objective of this research is to understand voters' perspective for Lokpal bill.
\end{abstract}

Index terms: Lokpal Bill, Lokayukt, Corruption, anti-corruption movement

\section{INTRODUCTION}

The formation of Democracy in India was a major movement after independence for building the fair political system defined as "Of the People, For the People and By the People". During the journey after independence, Indian democracy witnessed the paradigm shift from the experienced $\&$ dedicated political leaders to ornamental politicians and also burning issue of corruption made Indian citizens suspecting the honest democratic affairs [1].

The causes of corruption [2] in India include, "Excessive regulations, complicated taxes and licensing systems, numerous government departments each with opaque bureaucracy and discretionary powers, monopoly by government controlled institutions on certain goods and services delivery, 'and the lack of transparent laws and processes [3]".

The question may pinch each citizen, "Are we really living in a fair democratic environment? Is the system driving in the same direction and for the same purpose, for which our freedom fighters and policy makers dreamed of'? The answer may be a silence.

The Citizens of India witness corruption in Indian Political System which is growing steadily and dangerously and has become a 'Cancer' for the Nation. Different social worker such as Anna Hazare, Baba Ramdev came forward and started their movement against corruption and emphasised upon the implementation of Lokpal Bill.

The Lokpal, the anti-corruption supervisory body, is responsible to dealt with the Corruption against public functionaries. It represents the citizens of India and has jurisdiction over Central Government.

The Lokpal is responsible for enquiring into corruption charges at the national level while the Lokayukta performs the same function at the state level.

The journey of Lokpal Bill starts from year 1968 in the form of Jan Lokpal Bill, followed by amended proposals in year 1969, 1971, 1977, 1985, 1989, 1996, 1998, 2001, 2005, and in 2008 [11].

As a result to Anna Hazare movement for Jan Lokpal Bill in 2011, the ruling government passed the amended bill in 2011 . However, the government agreed upon only 15 points out of 71 recommended points, hence considered as a weak bill by anti-corruption activists. After 45 years of regular attempts, it could finally enacted on 18th December 2013.

With the appointment of chairperson of Lokpal Mr. Pinaki Chandra Ghose, the process of Lokayukt has started, however many states has yet to appoint. The Supreme Court asked the states the reason why the lokayukt has not been appointed.

\section{LITERATURE REVIEW}

In a 2011 report on Corruption in India [4] suggests, "High taxes and excessive regulation bureaucracy as a major reason for unethical public officials. The report recommends regulatory reforms, process simplification and lower taxes to reduce causes of corruption. Whenever objective standards and transparent processes are lost, and subjective opinion driven regulators and opaque/hidden processes are existing, the conditions inspire corruption [5].

Vito Tanzi [6] in an International Monetary Fund study suggests that in India, like other countries in the world, corruption is caused by excessive regulations and authorisation requirements, complicated taxes and licensing systems, mandated spending programmes, lack of competitive free markets, monopoly of certain goods and service providers by government controlled institutions, bureaucracy, lack of penalties for corruption of public officials, and lack of transparent laws and processes". The "Harvard University" study discovers these to be some of the "Causes of corruption and underground economy in India"[7].

The list of scams and scandals from year 1947 to 2018 is showing that the scams are gradually increasing in India year by year [8].

Revised Manuscript Received on August 25, 2019.

Amitabh Bhargava, Professor, Department of Management,

Uttaranchal University, Dehradun

Harsh Purohit, Professor \& Dean FMS-Wisdom, Banasthali

Vidyapith University, Rajasthan

Deepshikha Bhargava, Professor, University of Petroleum and Energy Studies, Dehradun 


\section{LOKPAL Bill - A powerful tool to control the Corruption: Opinion of Indian Voters'}

Garg Rishab, Sneha Ritwik (2012) talked about "major obstacles to effective democracy, Criminalization, corruption and power of money". They also discussed various "scandals and the list of scams from year 1947 to 2013" [1]

Nirvikar Singh (2010) explained the "corruption in Indian Political System which is growing steadily and dangerously and has become a CANCER for the Nation"'[2].

Manish Rajkoomar (2003) impressed upon the "loss of trust in politics and de-politicization criminalization of politics and corruption"[9].

The Jan Lokpal Bill (Citizen's Ombudsman Bill, improvements to the Lokpal and Lokayukta Bill 2011; discourage corruption, compensate citizen grievances, and protect whistle-blowers [10].

The literature review evidences that there is a need to cater the issue of corruption in Indian Political system but still this area is dreamed-off in India, for which each citizen is looking forward.

The researcher feels equal responsibility towards HE Dr. A. P. J. Abdul Kalam and his vision for citizen-centric e-governance; and also for Anna Hazare [12] and Baba Ramdev for their movement towards anti-corruption.

The objective of this paper is to assess Ranking on Challenges to Democracy of our nation and analyze Voters' Opinion Poll on Lokpal Bill.

\section{Methodology}

Here the Survey method is used to carry out the study to get the details from the respondents of different focus groups. The research instruments intended for the study are questionnaires, web based tools, interviews, discussion groups and social networking. Questionnaire is designed after careful analysis.

Sampling is purposive. The researcher keeps in mind that sample is representative; questionnaire undergoes Pilot testing, and test validity through well-defined management technique.

\section{A. Population and Sample Size}

Sample comprises of 1232 respondents (Type of profession, age, gender, income level, rural/urban, politicians, education level as criteria for classification) located throughout India (predominantly limited to netizens i.e. internet users outside Rajasthan/NCR). The sample is locale, mostly Rajasthan/NCR, however internet enabled farther reaches in the country and few cases of NRIs. Study does not limit itself to netizens within Rajasthan/NCR. A pan India sample is provided preliminary feel of Indians about the research theme.

\section{B. Tools of Data Analysis}

In this research, both qualitative and quantitative analysis is involved. Grounded theory of qualitative research is used. Statistical analysis is conducted through factor analysis, Chi-Square Test, Mean scores etc. using advanced Excel add-in tool for quick and accurate calculations.

\section{RANKING ON CHALLENGES TO DEMOCRACY OF OUR NATION}

To assess the ranking of different challenges to democracy of our nation, the respondents were asked to rank these functionaries on Likert Scale from 1 to 6 in order of priority from 1 as biggest challenge and 6 as smallest challenge.

From table 1 and graph 1, this can be observed that out of 1232 respondents, following results obtained:

i. Corruption has identified as biggest challenge by $25.17 \%$ respondents cumulatively.

ii. Poverty is ranked at second position by $18.23 \%$ respondents.

iii. At third place Casteism is identified as a challenge by $15.66 \%$ respondents.

iv. Illiteracy is ranked next by $14.88 \%$ respondents cumulatively.

v. Criminalization has been ranked fifth by $14.58 \%$ respondents.

vi. Finally, Gender Discrimination is ranked least by $11.48 \%$ respondents.

Thus it may be inferred that majority of respondents feel corruption is the biggest challenge to the democracy of our nation whereas Gender discrimination has identified as least significant challenge.

Table I: Ranking on Challenges to Democracy of our nation

\begin{tabular}{|c|c|c|c|c|c|c|c|c|}
\hline & \multicolumn{6}{|c|}{ Frequency of Ranks } & \multicolumn{2}{|c|}{ Calculation of Ranks } \\
\hline & \multicolumn{6}{|c|}{ Rank } & \multirow{2}{*}{ Total $^{\mathrm{z}}$} & \multirow{2}{*}{$\operatorname{Rank}^{\mathbf{y}}$} \\
\hline & 1 & 2 & 3 & 4 & 5 & 6 & & \\
\hline Corruption & $\begin{array}{c}63 \\
9\end{array}$ & $\begin{array}{c}38 \\
2\end{array}$ & $\begin{array}{c}17 \\
7\end{array}$ & 10 & 5 & 19 & 6511 & 1 \\
\hline Poverty & $\begin{array}{c}14 \\
7\end{array}$ & $\begin{array}{c}34 \\
5\end{array}$ & $\begin{array}{c}27 \\
0\end{array}$ & $\begin{array}{c}21 \\
3\end{array}$ & $\begin{array}{c}13 \\
4\end{array}$ & $\begin{array}{c}12 \\
3\end{array}$ & 4717 & 2 \\
\hline Castesim & 86 & $\begin{array}{c}16 \\
1\end{array}$ & $\begin{array}{c}24 \\
7\end{array}$ & $\begin{array}{c}34 \\
4\end{array}$ & $\begin{array}{c}31 \\
7\end{array}$ & 77 & 4052 & 3 \\
\hline Illiteracy & $\begin{array}{c}18 \\
6\end{array}$ & 99 & $\begin{array}{c}17 \\
9\end{array}$ & $\begin{array}{c}21 \\
4\end{array}$ & $\begin{array}{c}32 \\
6\end{array}$ & $\begin{array}{c}22 \\
8\end{array}$ & 3849 & 4 \\
\hline $\begin{array}{c}\text { Criminalizatio } \\
n\end{array}$ & $\begin{array}{c}14 \\
7\end{array}$ & $\begin{array}{c}14 \\
2\end{array}$ & $\begin{array}{c}19 \\
9\end{array}$ & $\begin{array}{c}19 \\
5\end{array}$ & $\begin{array}{c}25 \\
1\end{array}$ & $\begin{array}{c}29 \\
8\end{array}$ & 3773 & 5 \\
\hline Discrimination & 27 & $\begin{array}{c}10 \\
3\end{array}$ & $\begin{array}{c}16 \\
0\end{array}$ & $\begin{array}{c}25 \\
6\end{array}$ & $\begin{array}{c}19 \\
9\end{array}$ & $\begin{array}{c}48 \\
7\end{array}$ & 2970 & 6 \\
\hline
\end{tabular}

${ }^{z}$ Rank Calculation $=$

Rank $1 * 6+\operatorname{Rank} 2 * 5+\operatorname{Rank} 3 * 4+\operatorname{Rank} 4 * 3+\operatorname{Rank} 5 * 3+\operatorname{Rank} 6 * 1$

${ }^{y}$ Cumulative Rank calculated using Rank(Rank, Range) Function where Rank is on Likert Scale from 1-6 in order of priority)

$(1=$ Biggest challenge, $6=$ Smallest challenge $)$

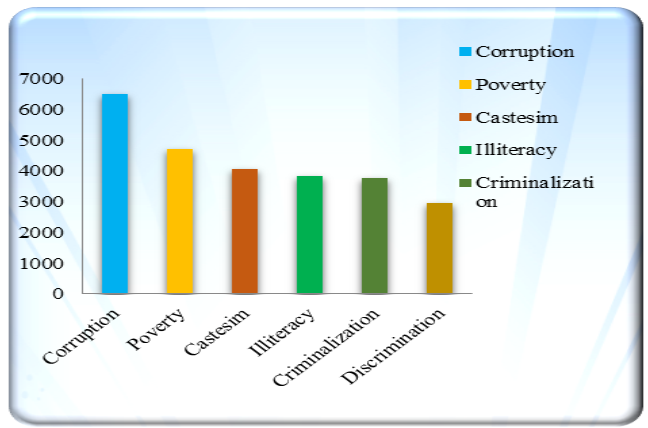

Fig. 1. Ranking on Challenges to Democracy of our nation 


\section{VOTERS' OPINION POLL ON LOKPAL BILL}

The purpose of this section is to analyze the voters' opinion poll on role of anticorruption movements and Lokpal Bill. Following analysis showing the criteria wise interpretation on factors influencing voters:

\section{A. Voters' opinion on anticorruption movements by the social workers helps to put pressure on the government against corruption}

From the figure and table shown below, it can be observed that out of 1232 respondents, total $808(299+509)$ i.e. $66 \%$ respondents were highly agree that the anticorruption movements helps to put pressure on the government against corruption. Total $212(158+54)$ i.e. $17 \%$ were disagree with this statement. At the same time $212(17 \%)$ respondents were neutral/unresponsive on this issue.

Thus it may be concluded that the majority feel that the anticorruption movements by the social workers like Shri Aana Hazare, helps to put pressure on the government against corruption.

Table II: Voters' opinion on anticorruption movements by the social workers helps to put pressure on the government against corruption

[Rating on Likert Scale from Strongly agree to Strongly Disagree]

\begin{tabular}{|c|c|c|}
\hline & $\begin{array}{c}\text { Total } \\
\text { Respondents }\end{array}$ & Percentage of Respondents \\
\hline Strongly Agree & 299 & $24 \%$ \\
\hline Agree & 509 & $41 \%$ \\
\hline Neither & 212 & $17 \%$ \\
\hline Disagree & 158 & $13 \%$ \\
\hline $\begin{array}{l}\text { Strongly } \\
\text { Disagree }\end{array}$ & 54 & $4 \%$ \\
\hline
\end{tabular}

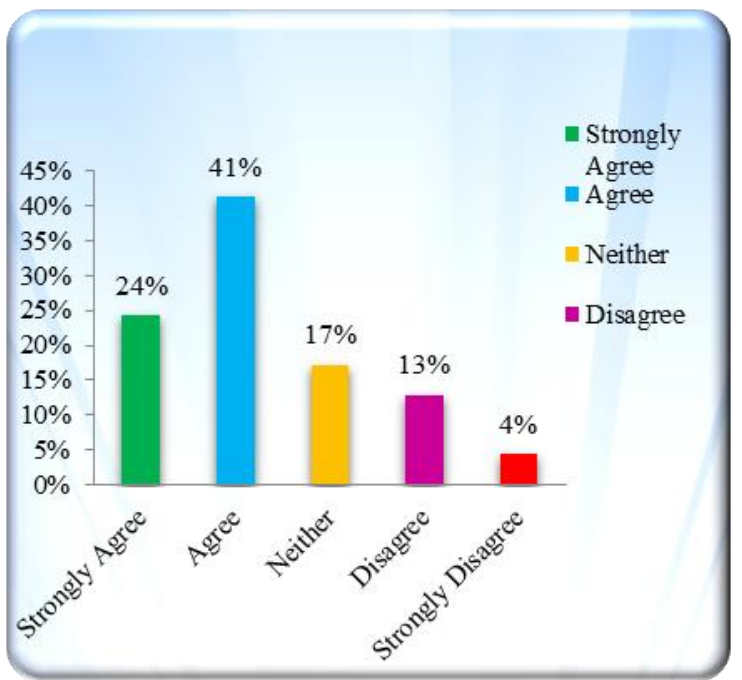

Fig. 2. Voters' opinion on anticorruption movements by the social workers helps to put pressure on the government against corruption

\section{B. Responses on LOKPAL Bill as a powerful tool to control the Corruption}

From the figure and table shown below, it can be interpreted that out of 1232 respondents, total $856(203+653)$ i.e. $69 \%$ respondents were highly agree that the LOKPAL Bill is a powerful tool to control the Corruption. Total 164 $(123+41)$ i.e. $13 \%$ were disagree with this statement. Remaining 212 (17\%) respondents were neutral/unresponsive on this issue.

Thus it may be inferred that the majority feel that the LOKPAL Bill is a powerful tool to control the Corruption.

Table III: Responses on LOKPAL Bill as a powerful tool to control the Corruption

[Rating on Likert Scale from Strongly agree to Strongly Disagree]

\begin{tabular}{|c|c|c|}
\hline & $\begin{array}{c}\text { Total } \\
\text { Respondents }\end{array}$ & Percentage of Respondents \\
\hline Strongly Agree & 203 & $16 \%$ \\
\hline Agree & 653 & $53 \%$ \\
\hline Neither & 212 & $17 \%$ \\
\hline Disagree & 123 & $10 \%$ \\
\hline Strongly Disagree & 41 & $3 \%$ \\
\hline
\end{tabular}

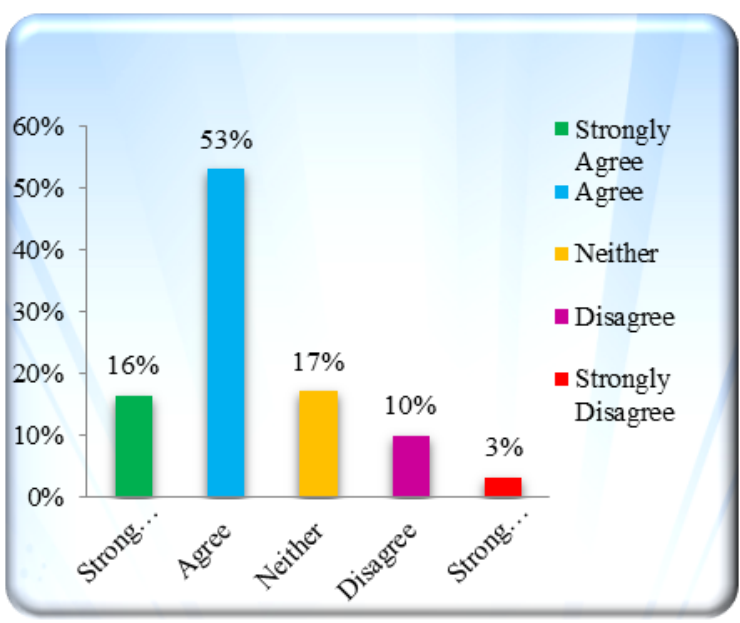

Fig. 3. Responses on LOKPAL Bill as a powerful tool to control the Corruption

\section{Opinion poll on LOKPAL Bill implementation in all states of India}

From the figure 4 and table 4 shown below, it can be interpreted that out of 1232 respondents, total 1013 $(489+524)$ i.e. $83 \%$ respondents were highly agree that the LOKPAL Bill should be immediately implemented in all states of India. Total $115(123+41)$ i.e. $9 \%$ were disagree with this statement. Remaining $104(8 \%)$ respondents were neutral/unresponsive on this issue.

Thus it may be concluded that the majority feel that the LOKPAL Bill should be immediately implemented in all states of India. 


\section{LOKPAL Bill - A powerful tool to control the Corruption: Opinion of Indian Voters'}

Table IV: Opinion poll on LOKPAL Bill implementation in all states of India [Rating on Likert Scale from Strongly agree to Strongly Disagree]

\begin{tabular}{|c|c|c|}
\hline & $\begin{array}{c}\text { Total } \\
\text { Respondents }\end{array}$ & $\begin{array}{c}\text { Percentage of } \\
\text { Respondents }\end{array}$ \\
\hline Strongly Agree & 489 & $40 \%$ \\
\hline Agree & 524 & $43 \%$ \\
\hline Neither & 104 & $8 \%$ \\
\hline Disagree & 62 & $5 \%$ \\
\hline Strongly Disagree & 53 & $4 \%$ \\
\hline
\end{tabular}

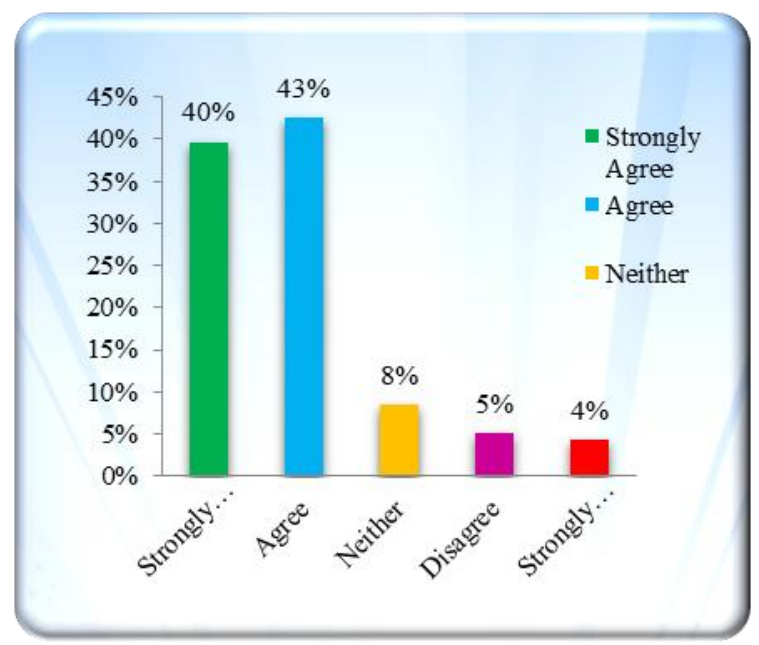

Fig. 4. Opinion poll on LOKPAL Bill implementation in all states of India

\section{CONCLUSION \& RECOMMENDATIONS}

This research was an endeavor to assess the voter's opinion for Lokpal bill and to identify the necessity of the same.

The researcher embraced the assessment of these key identifiers on the sample size of 1232 out of which $99.84 \%$ were Indian citizens and were eligible to vote, out of which just $67 \%$ could cast the vote in their constituency. The Sample size was comprised of $71 \%$ Men and $29 \%$ Women.

In this research, the perspectives of Academicians, Corporate Professionals, Students, Businessmen/Self Employed, Un-instructed national Urban, House Wife, Doctors, Un-taught native Rural, Senior Citizens, Governments Officials, Farmers, Journalists/Media, Social Workers/NGO, Politicians/Youth Leaders; were taken into consideration.

The investigation secured responses from four primary areas of India: $37 \%$ from Jaipur, $15 \%$ rest urban areas of Rajasthan, $17 \%$ from NCR Region and 32\% PAN India other than Rajasthan and NCR.

The respondents' opinion regarding challenges on Democracy illustrates that about $25 \%$ citizens measured 'Corruption' as the leading challenge to our democracy.

To assess the attitude of Indian Citizens about need and procedure of Lokpal bill in India, voters' Opinion Poll was obtained on parameters the anticorruption developments sets pressure on the government against corruption (66\% concurred); LOKPAL Bill is a powerful tool to control the Corruption (69\% concurred); LOKPAL Bill ought to be instantly actualized in all states of India ( $83 \%$ concurred). a. The important ranking about challenges to our democracy, 'Corruption' was rated as the biggest challenge by a majority of respondents. Here is a need to apply an effective strategy to control the corruption in the system to retain citizens' trust in our existing functionaries.

b. The analysis shows that majority of voters are in favor of anti-corruption movements and Lokpal bill, the functionaries should respect the feeling of the citizens and should support this kind of Movements, instead of suppressing.

\section{REFERENCES}

1. Rishab Garg \& Ritwik Sneha (2012). Electoral Reforms: An Approach To Effective Democracy. Legal Services India.

2. Nirvikar Singh (2010) The trillion-dollar question. The Financia Express. December 19. Accessed 9 Oct 2012

3. Survey on Bribery and Corruption (2011)- Impact on Economy and Business Environment. KPMG.

4. Corruption in India - A rotten state. The Economist. 10 March 2011

5. Myint (December 2000). CORRUPTION: CAUSES, CONSEQUENCES AND CURES". Asia-Pacific Development Journal 7 (2)

6. Vito Tanzi (December 1998). Corruption Around the World - Causes, Consequences, Scope, and Cures 45 (4). IMF Staff Papers

7. Anant and Mitra (November 1998). The Role of Law and Legal Institutions in Asian Economic Development: The Case of India. Harvard University

8. http://forum.topnews.in/threads/4861-List-Of-Scams-In-India

9. Manish Rajkoomar, Essay On The Electoral Reforms In Contemporary India

10. What is the Jan Lokpal Bill, why it's important. NDTV. 16 August 2011. Retrieved 17 August 2011

11. https://en.wikipedia.org/wiki/Lokpal

12. Anna, Jan Lokpal Bill top FB status updates in 2011(2011) . CNNIBN 09 Dec 2011. Retrieved 5 June 2012.

13. Lokpal: Delay in appointment of Lokpal \& Lokayukta: Who will bel the graft? - The Economic Times https://m.economictimes.com/news/politics-and-nation/why-there-isno-lokpal-at-centre-and-lokayukta-in-many-states/articleshow/66570 $168 . \mathrm{cms}$

14. Lokpal Bill tabled in RS, sent to select committee - Politics - Politics News - ibnlive (2012). Ibnlive.in.com. 21 May 2012. Retrieved 29 May 2012

15. Lokpal Bill: Govt version vs civil society version (2011). The Times of India. 7 April 2011. Retrieved 7 April

\section{AUTHORS PROFILE}

Amitabh Bhargava is Professor, Department of Management, Uttaranchal University, Dehradun, he is Ph.D, MBA

Harsh Purohit, Professor \& Dean FMS-Wisdom, Banasthali Vidyapith University, Rajasthan. He has published many research paper.

Deepshikha Bhargava is currently Professor, University of Petroleum and Energy Studies, Dehradun . She is hase Master Degree (Computer Science), JRN Rajasthan Vidyapith University, Udaipur and Ph.D.(Computer Science),Banasthali Vidyapith University

Her Area of Specialization are AI, Nature Inspired Computation, Software Agents.

\section{Recommendations}

